The Journal of Society and Media, October 2020, Vol. 4(2) 406-424

https://journal.unesa.ac.id/index.php/jsm/index

E-ISSN 2580-1341 and P-ISSN 2721-0383

Accredited KEMENRISTEK/BRIN No.148/M/KPT/2020

DOI: 10.26740/jsm.v4n2.p406-424

\title{
Publicity of Sido Muncul Corporate Social Responsibility News Content During Covid-19 Pandemic
}

\author{
Steven Leo Naryi Lukman ${ }^{1 *}$, Rustono Farady Marta ${ }^{2}$, Sugeng Wahjudi ${ }^{3}$ \\ ${ }^{1}$ Master's Degree of Communication Science Department, Postgraduate Studies, \\ Universitas Bunda Mulia, Tangerang, Banten 15143, Indonesia \\ Email: stevenleo250@gmail.com
}

${ }^{2}$ Master's Degree of Communication Science Department, Postgraduate Studies, Universitas Bunda Mulia, North Jakarta, Jakarta 14430, Indonesia

Email: rmarta@bundamulia.ac.id

${ }^{3}$ Communication Science Department, Faculty of Social Sciences and Humanities, Universitas Bunda Mulia, North Jakarta, Jakarta 14430, Indonesia

Email: swahjudi@bundamulia.ac.id

\begin{abstract}
The COVID-19 pandemic which took place in Indonesia in 2020 was an adverse event for various sectors in the country. This case attracted a high level of public attention. Various companies engaged in carrying out corporate social responsibility activities in helping areas affected by COVID-19, one of which was PT. Sido Muncul. CSR activities help companies to get a positive image and maintain customer loyalty through publicity on the online news portal. The purpose of this research is to describe the contents of the news on the online news portal about corporate social responsibility carried out by PT. Sido Muncul during the COVID-19 pandemic. The results of this paper, will describe in detail the types of news issued to report on CSR carried out by it. the researcher choose to analyze with content analysis method by Wimmer and Dominick, this method including; describe the contents of communication, to know about the characteristics of the message, and to supports the study of the effects of mass media. In gathering information and data, the study used qualitative approach with content analysis methods for 8 news items released by various online news portals during the COVID-19 pandemic, starting from March 2, 2020.
\end{abstract}

Keywords: corporate social responsibility, pandemic, publicity

Paper type: Research paper

*Corresponding author: stevenleo250@gmail.com

Submitted: 2020-07-10; Accepted: 2020-10-30; Published: 2020-10-30

Cite this document: Lukman, Steven Leo Naryi, Rustono Farady Marta, and Sugeng Wahjudi. (2020). Publicity Of Sido Muncul Corporate Social Responsibility News Content During Covid-19 Pandemic. The Journal of Society and Media, 4(2), 406-424. DOI: $10.26740 /$ jsm.v4n2. 406-424 
Lukman: Publicity of Sido Muncul

Corporate Social Responsibility News

Content During Covid-19 Pandemic

\section{INTRODUCTION}

In 2020, there was a pandemic in all parts of the world which resulted in huge losses in various sectors, starting from the slowing economy, the overwhelmed health sector, to politics and education. This pandemic comes with the emergence of COVID-19 disease caused by the Coronavirus.

According to WHO on page who.int (WHO | World Health Organization, n.d.), most people infected with the COVID-19 virus will experience symptoms such as mild to moderate respiratory illness and recover without requiring special treatment. People who are more likely to develop serious illnesses are older people and those with basic medical problems such as cardiovascular disease, diabetes, chronic respiratory disease, and cancer. COVID-19 disease is also present and spread in Indonesia. Government Spokesperson for Corona Virus Handling, Achmad Yurianto reported, monitoring up to 22 May 2020 there were 46,845 Covid-19 cases in Indonesia as of the first case announced by President Joko Widodo on March 2, 2020. 18,735 Covid-19 patients have been cured. Conversely, as many as 2500 patients were recorded dead.

This event caused huge losses in many countries, including in the world economy. Business ventures from various lines become weak, both from the consumer side to the staff of the employee's employees, due to the implementation of social distancing regulations or maintaining distance from the people around and are urged for workers to work from their respective homes.

PT. Sido Muncul, is one of the largest pharmaceutical companies that has long been established in Indonesia with a variety of superior products. In the COVID-19 pandemic, Sido Muncul also felt the decline in production activities in UMKM in the community. Responding to the incident, Sido Muncul compiled a number of strategies to provide support and carry out its social responsibilities to the community in order to maintain its image as one of the largest pharmaceutical companies in Indonesia. One of the efforts made by Sido Muncul is to carry out Corporate Social Responsibility activities or also abbreviated as CSR.

CSR is a way to increase the value of a company to the public and also to the public awareness of the company that can be shown by the intensity of the publicity that exists. (Servaes and Tamayo 2013). As one of the way to reconnect with the people, a corporation should be think a strategy to made a CSR strategies 
and giving a clear image of the corporate to the people. (Widhagdha, Wahyuni, and Sulhan 2019) With the COVID-19 pandemic, CSR can be an effective way to keep the company closer to the public in order to improve the image of the company and products while maintaining customer loyalty.

PT. Sido Muncul distributed a variety of donations to the regions of Indonesia affected by COVID-19. Distribution of PT. Sido Muncul like herbs and herbs given free to the surrounding community. In addition, PT. Sido Muncul also attracts other stakeholders such as the government, local UMKM, and hospitals to distribute their assistance.

Business and communication are two inseparable things, like two interconnected currencies. The purpose of business and communication is to achieve mutual interests and understanding. While the aim of CSR is the sustainability of the company itself, and it is important to do for all companies without exception in order to provide positive benefits both internally and externally (Hardhiyanti and Rasyid 2018). The key to the success of this CSR is communication and of course it will help increase the collective awareness of the community about the company's existence. Efforts to communicate CSR effectively will be very good in building a good image of the company and educating the public to be aware of its potential benefits. The broad advantage is that it reduces the chances of dealing with social volatility (Situmeang 2017). Several Studies also has been proved that engaging a CSR activities delivers a lot of positive benefits including access to valuable resources, reducing price sensitivity, enhacing marketing effort and increasing demand that will led to incrasing revenue stream. (Rahman, Rodríguez-Serrano, and Lambkin 2017). On way to communicate CSR activities to society is by using publicity written by media. The Indonesian Internet Service Providers Association (APJII) explained 143.26 inhabitants of Indonesia in 2017 using the Internet. Related to this fact, people often look for information that is quickly obtained and has credibility, both information about the latest events or an organization (Marta, Fernando, and Kurniawati 2020). Online news portal is one of the impacts of the presence of the internet which is slowly replacing conventional media, such as television, newspapers, and radio, as a medium in disseminating information on events that occur on the world even just a few seconds ago. Nowadays, people use online news portal to gather informations about important events in the world, rather than 
conventional media. Thus, the publicity on the online news portal allows it to be seen by more audiens everywhere. CSR activities as above can be strengthened by publicity by the mass media and new media. According to Gilaninia, Taleghani and Mohammadi (Gilaninia, Taleghani, and Mohammadi 2013), the role of a public relations will need a good planning and execution to show th good will of the company and it does not easily obtained by a company, in fact that we must create and maintain the strategy that public relation is to create goodwill and understanding.

According to Heryanto (Heryanto and Rumaru 2015), publicity is the delivery of information that is designed to generate higher interest in individuals or companies through information media without spending costs due to consideration of the large amount of public interest. Meanwhile, according to Lawrence and Dennis L. Wilcox in Heryanto \& Rumaru (Heryanto \& Rumaru, 2015), publicity is information that does not need to pay for its reporting or broadcast space, but at the same time cannot be controlled by the individual or company that provides the information. As a result, information can lead to the formation of images and influence the people and can result in actions, where these actions can be beneficial or detrimental when information is published. Publicity as a result of media relations is the responsibility of the company's public relations role. In many cases, this division is also a strategic manager of the company's CSR activities. According to the researcher, by seeing the important role of CSR activities and publicity in the governance of PT. Sido Muncul during the COVID-19 pandemic, it was interesting to observe and analyze the publicity reported by the media regarding CSR activities carried out by PT. Sido Muncul.

Corporate social responsibility or Corporate Social Responsibility (CSR) is a strategy or agenda undertaken by the company to create a good corporate image, respond to consumer social concerns, and develop positive relationships and images with consumers and other stakeholders Frederick in Ubius and Alas (Übius and Alas 2009) argues that social responsibility in the final analysis implies a public attitude towards society's economy and human resources and a willingness to see that these resources are used for broad social purposes and not only for narrowly constrained personal and corporate interests. 
According to Drucker (Drucker 1982), The social responsibility that can be said to be right from business sight is to turn social problems into economic opportunities and economic benefits, into productive capacities, into human competencies, into well-paid jobs, into wealth. Corporate Social Responsibility has several dimensions as follows: (1) CSR awareness, according to (Pomering and Dolnicar 2009), awareness of CSR is more about whether a real CSR activity is realized by customers or society; (2) Trust in CSR, belief in CSR can generally be defined as that a company, which acts as a sponsor of a CSR activity, can be willing to keep promises and be responsible for fulfilling obligations with honesty, good intentions and non-opportunistic goals. (Tian, Wang, and Yang 2011) CSR activities mean the company's ability to humanly be able to respond to social conditions that occur in the surrounding environment. Apart from being enjoyed and utilized by the surrounding environment, this social responsibility also provides benefits, especially in the creation, improvement and maintenance of the company's image in the eyes of the public.

Community relations in practice is intended for the public who intersect directly with the organization. But there are also business organization's community relations activities that target more than audiences who are in direct contact with their business processes. This is done to strengthen the bond between the organization and the community, and the next goal is to get media attention. According to Grubor \& Milovanov in (Išoraite 2018), brand image is a unique blend of functional and emotional characteristics that consumers perceive as added value, unique experiences, and fulfillment of promises. It has a symbolic value distinct from anything that is available in reality, and the ability to represent interests that go beyond the brand itself. For companies, it is a core strategic resource and the most powerful invaluable asset.

Not only presents a theoretical landscape, the Field of Corporate Social Responsibility (CSR) also develops an approach, which is controversial, complex and unclear. Garriga and Melé (Garriga and Melé 2004) tries to clarify the situation, "mapping the territory" by classifying the main CSR theories and related approaches into four groups: (1) instrumental theory, in which a corporation or a company is only seen or viewed as an instrument for creating wealth, and the social activities they do are only as a means of achieving economic results for their benefit; (2) political theory, which focuses on the power 
of corporations in society and the responsible use of this power in the political arena; (3) integrative theories, a condition or situation where the corporation is focused on satisfying social demands; and (4) is the company's ethical responsibility to society. These four aspects must be included in CSR, so that it can only be said that the following is an appropriate concept of business and community relations. Although most theories studied do not make it explicit, one can appreciate the tendency to overcome these deficits.

There are five pillars that are that are proposed by the Prince of Wales International Business Forum are (Wibisono 2007) that comprehensive enough to underlie CSR activities that are generally carried out by companies. The five pillars are: (1) building human capital, in which the company seeks to get support from its internal environment, by creating reliable human resources (employees), as well as from its external environment through empowering the surrounding community; (2) strengthening economics, companies are asked to not only take profits, but also have to empower the economy of the surrounding community; (3) assessing social cohesion, companies are required to maintain harmony with surrounding communities so as not to cause conflict; (4) encouraging good corporates governance, companies must carry out good business governance, and (5) to protecting the environment, the company is also responsible for environmental sustainability.

According to Sen and Bhattacharya in Lichtenstein, Drumwright, and Braig (Lichtenstein, Drumwright, and Braig 2004), people identify with organizations that they believe, or would like to believe, that they are of the same nature and which give them a sense of self-improvement. By applying this logic, when a company behaves in a way that is considered socially responsible, it can be concluded that consumers are likely to perceive that the company has certain desirable traits that resonate with their sense of self. As a result, consumers are more likely to identify with the corporation; in doing so, they behave in a way that supports the company's goals. The relationships that exist between brands and consumers during times of crisis can be even more meaningful than the relationships they have during "quiet" times. Therefore, a pandemic like this offers a great opportunity for companies to actively carry out their CSR strategies and agendas (He and Harris 2020). 
Research conducted by Yoon, Gurhan-Canli, and Schwarz (Yoon, GürhanCanli, and Schwarz 2006) states that CSR activities enhance a company's image when consumers associate sincere motives. Variables that influence perceptions of sincerity include the salience of benefits from the cause, the sources from which consumers learn about CSR, and the ratio of CSR contributions and CSR-related advertising. it will be very ineffective if the sincerity of the motive is unclear, and it will damage the company's image when the motive is deemed insincere.

According to Shu and the others (Shu et al. 2020), Social media has become a main source of news that almost everyone has access to it, it become one of the channel to spread news in free and will be easy to access for everyone it helps people to express their opinions publicly and a great way for individual to consume an information. (Ahmed and Cho 2019). The press and mass media will always be maintain and enhance their communicative power, but people will use the new media to also strengthen their communicative power to each other as one network (Newman, Dutton, and Blank 2014). Sumadiria (2005) in Ahditia (Ahditia 2011) divides news by type into seven groups as straight news, depth news, comprehensive news, interpretative report, feature story, depth reporting, and investigative reporting.

Straight news report is a direct report about an event. Usually, this type of news is written with elements starting with what, who, when, where, why, and how $(5 \mathrm{~W}+1 \mathrm{H})$. Depth news report gather information with facts about the event itself as additional information for the event. This type of report requires the transfer of information, not the opinion of the reporter. The real facts are still great. Comprehensive news are reports about facts that are comprehensive in terms of various aspects. Comprehensive news tries to combine various pieces of fact in one story building events so that the red thread is clearly seen. Interpretative report usually focuses on a controversial issue, problem, or event. The focus of the news report is still talking about facts that are proven not opinions. Interpretive reports are usually to answer the question why. Feature story is look for facts to attract the attention of their readers, not so presenting information that is important to their readers. Feature writers present a reader experience that depends more on writing style and humor than the importance of the information presented. Depth reporting is deep, sharp, complete and intact about a phenomenal or actual event. In-depth reporting is presented in several 
Lukman: Publicity of Sido Muncul

Corporate Social Responsibility News

Content During Covid-19 Pandemic

headings to avoid reader boredom. Lastly, in Investigative reporting, reporters conduct an investigation to obtain hidden facts for the purpose.

The purpose of publicity according to Heryanto and Rumaru (Heryanto and Rumaru 2015) is; (1) get attention, in which to attract the attention of the public to an issue or event that was made in a planned manner and it would be better if the mass media review it continuously; (2) receive an award, publicity is needed to elevate the prestige of an institution or company. Planned and systematically, the institution or candidate is positioned to be "important" in the minds and agenda of the audience; (3) good intentions, the will of the other party to hold discussions that lead to cooperative efforts.

Wartick's study of publicity in Spotts and Weinberger (Spotts, Weinberger, and Weinberger 2014) identifies that media exposure has a different effect on companies depending on their existing reputation. According to (Pujadi 2010), this brand image indicator can be divided into several indicators: (1) Professional Impression: A product will have an image that has expertise in its field; (2) Modern Impression: A product will have an image that does have technology that will keep abreast of the times; (3) Serve all segments: A product does not serve a particular segment but serves almost all existing segments; (4)Attention to Consumers: A product has a concern for consumers. Companies with a strong reputation benefit from a higher volume of media exposure resulting in a bigger and more positive reputation change. (Skard and Thorbjørnsen 2014) study also shows that non-corporate sources (such as publicity) produce a more positive brand evaluation than corporate sources (such as advertising) when the sponsor has a positive reputation. PT. Sido Muncul is a large company that has been established for a long time and has a high reputation and a long track record. Of course, by good publicity has an important influence in maintaining the reputation that they already had.

The novelty of this research is very crucial and interesting opportunity, because the researcher can examine news that occurs in critical conditions / phenomena in the world, which is very rare. due to the recent pandemic conditions, researchers have not been able to found similar studies in this pandemic related studies. this research is an opportunity that is eagerly awaited and interesting for the researcher to be investigated further. Therefore, the purpose 
of this discussion is to analyze the news related to CSR activities of PT. Sido Muncul to map the attributes that appear in the news. These attributes will then be discussed one by one to see the importance in the reporting process.

\section{METHOD}

The researchers decided to analyze the news about CSR activites which was done to PT. Sido Muncul, from several news portal with the highest traffic in Indonesia in 2020. Other supporting data that serve as secondary data such as literature, journals, books, and so on. For gathering information and data a qualitative approach is used. The qualitative approach is intended to give meaning to a phenomenon, dominated by inductive reasoning (Danim 2002). According to Danim (Danim 2002), qualitative research that is descriptive in nature is describing events or events that are factual. Research is intended only to make a description or narrative solely of a phenomenon, not to look for relationships between variables, test hypotheses, or make predictions.

For analyzed the news texts, the researcher decided to use content analysis techniques. Kolbe and Burnett's in Lombard, Snyder-Duch, and Bracken (Lombard, Snyder-Duch, and Bracken 2002) definition states that content analysis is "an observational research method that is used to systematically evaluate the symbolic content of all forms of recorded communication. These communications can also be analyzed at many levels (image, word, roles, etc.), thereby creating a realm of research_opportunities." Berger (Berger 2011) also stated that content analysis is a research technique for classifying systematically and describing communication content based on predetermined categories.

Wimmer and Dominick in Widiasari (Widiasari 2012) reveal three uses of the content analysis method, including; describe the contents of communication, to know about the characteristics of the message, and to supports the study of the effects of mass media. Setiawan in Widiasari (Widiasari 2012) describes the content analysis method is basically a research technique that intends to describe the message attributes. Four message attributes that will be analyzed by the author are divided into types of news, completeness of news elements, author's opinion, and news tendency. With this method, the researcher believes that he can examine some of the news in the media, to be more specific and targeted. so as to make accurate conclusions at the end of this study. 
For the first one, types of news attributes studied by looking at each news characteristics (straight news, depth news, etc). Each type of news has the ability to attract the attention of a different audience. For the second one, completeness of News Elements attributes studied by looking at news element that consists of what, who, where, why, when, and how $(5 \mathrm{~W}+1 \mathrm{H})$. The third one is, author's Opinion attributes studied by looking at conclusions or opinions from document authors/journalists. There are times when reporters or document writers framing or framing the news covered, so that readers have a certain tendency towards the news. For the last one is news Tendency attributes studied by looking at the contents of the document coverage regarding the company / individual in the document are negative, positive, or neutral. because in making an article or news, of course there is something you want to highlight in every writing. whether it's the positive or negative part of something in the incident. then the researcher also feels very necessary to see clearly, where is the direction of the news writer or article in making the news or article, in this case about CSR which is done by one of the big companies PT. Sido

To describe the contents of communication can be easily done by making several comparisons. The comparisons used in this research is inter-message analysis, which is a comparison of the contents of communication at different times, situations, or audiences. In this case, the study of a set of documents.

\section{Table 1}

News Portals with the Highest Traffic in Indonesia in 2020.

\begin{tabular}{cccc}
\hline NO. & Press Name & NO. & Press Name \\
\hline 1 & Okezone.com & 6 & Liputan6.com \\
2 & Tribunnews.com & 7 & Merdeka.com \\
3 & Detik.com & 8 & Suara.com \\
4 & Kompas.com & 9 & Kumparan.com \\
5 & Sindonews.com & 10 & Idntimes.com \\
\hline
\end{tabular}

Source: Alexa.com

Object of this research is news related to CSR activities carried out by PT. Sido Muncul during the COVID-19 pandemic which began on March 2, 2020. News text was taken from the 10 most popular news portals in Indonesia in 2020 according to Alexa(Anon n.d.). The more popular the news portals, the more 
audiens are reached to see the publicity of CSR. From these 10 news portals, only Tribunnews.com, Detik.com, Kompas.com, Sindonews.com, Liputan6.com, Suara.com, and Kumparan.com contains publicity of PT. Sido Muncul CSR activities during COVID-19 pandemic.

Table 2

COVID-19 News Between Choosen Timeline

\begin{tabular}{|c|c|c|c|}
\hline No. & Date & Title & Press Name \\
\hline 1 & $\begin{array}{l}22^{\text {nd }} \\
\text { of } \\
\text { March }\end{array}$ & $\begin{array}{l}\text { Lindungi Lansia dari Wabah Covid-19, Sido } \\
\text { Muncul Sumbang Tolak Angin }\end{array}$ & Detik.com \\
\hline 2 & $\begin{array}{l}23^{\text {rd }} \text { of } \\
\text { March }\end{array}$ & $\begin{array}{l}\text { Bos Sido Muncul Bagi-Bagi Sembako ke } \\
\text { Warga Haji Abu }\end{array}$ & Detik.com \\
\hline 3 & $\begin{array}{l}5^{\text {th }} \text { of } \\
\text { April }\end{array}$ & $\begin{array}{l}\text { Bantu Penanganan Covid-19, Sido Muncul } \\
\text { Guyur Dana Rp } 15 \text { Miliar }\end{array}$ & Suara.com \\
\hline 4 & $\begin{array}{l}15^{\text {th }} \text { of } \\
\text { April }\end{array}$ & $\begin{array}{l}\text { Sido Muncul Bagikan 1.000 Paket Sembako } \\
\text { untuk Warga Terdampak Covid-19 di Bekasi } \\
\text { Barat }\end{array}$ & Tribunnews.com \\
\hline 5 & $\begin{array}{l}17^{\text {th }} \text { of } \\
\text { April }\end{array}$ & $\begin{array}{l}\text { Gandeng Warteg, Bos Sido Muncul Bagikan } \\
600 \text { Paket Makanan Tiap Hari }\end{array}$ & Detik.com \\
\hline 6 & $\begin{array}{l}18^{\text {th }} \text { of } \\
\text { April }\end{array}$ & $\begin{array}{l}\text { Dampak Covid Meluas, Sido Muncul } 6.000 \\
\text { Paket Sembako }\end{array}$ & Kompas.com \\
\hline 7 & $\begin{array}{l}23^{\text {rd }} \text { of } \\
\text { April }\end{array}$ & $\begin{array}{l}\text { Sido Muncul Sumbang Bantuan Rp } 820 \text { Juta } \\
\text { untuk Warga Terdampak Covid-19 }\end{array}$ & Kumparan.com \\
\hline 8 & $\begin{array}{l}19^{\text {th }} \text { of } \\
\text { May }\end{array}$ & $\begin{array}{l}\text { Hadapi Pandemi Covid-19, Sido Muncul } \\
\text { Komitmen Salurkan Bantuan Senilai Rp } 15 \\
\text { Miliar }\end{array}$ & Kompas.com \\
\hline 9 & $\begin{array}{l}20^{\text {th }} \text { of } \\
\text { May }\end{array}$ & $\begin{array}{l}\text { Komitmen Kucurkan Rp } 15 \text { Miliar, Sido } \\
\text { Muncul Kembali Beri Bantuan buat Hadapi } \\
\text { Covid-19 }\end{array}$ & Liputan6.com \\
\hline 10 & $\begin{array}{l}16^{\text {th }} \text { of } \\
\text { June }\end{array}$ & $\begin{array}{l}\text { Produsen Jamu Ini Sumbang } 1.500 \text { Botol } \\
\text { Herbal untuk Pasien Covid-19 }\end{array}$ & SINDONews.com \\
\hline 11 & $\begin{array}{l}17^{\text {th }} \text { of } \\
\text { June }\end{array}$ & $\begin{array}{l}1500 \text { JSH Herbal untuk Bantu Pemprov Jatim } \\
\text { Tekan Korban Covid-19 }\end{array}$ & Liputan6.com \\
\hline 12 & $\begin{array}{l}22^{\text {nd }} \\
\text { of } \\
\text { June }\end{array}$ & $\begin{array}{l}\text { Bantu Pemprov Jatim Tekan Korban Covid- } \\
\text { 19, Sido Muncul Bagikan JSH Herbal } \\
\text { Tingkatkan Umum }\end{array}$ & Tribunnews.com \\
\hline
\end{tabular}

Source: Google.com

\section{RESULTS AND DISCUSSION}

Based on the five pillars put forward by Wibisono, the CSR activities of PT. Sido Muncul to fulfill two pillars which are Building Human Capital and Strengthening Economy. 
CSR activities of PT. Sido Muncul is considered to meet the first pillar, because the donation assistance given by PT. Sido Muncul is a form of empowering the surrounding environment. This was stated in the Detik.com news "Sido Boss Appears to Share Basic Needs for Haji Abu Residents" where PT. Sido Muncul to hook up the efforts of the local warteg in distributing food packages to residents affected by COVID-19.

CSR activities of PT. Sido Muncul is also considered to fulfill the second pillar, because the target of CSR activities is aimed at people whose economies are weakened due to the impact of the COVID-19 pandemic.

The discussion of the research was obtained through twelve news articles from various sources which contained the publicity of CSR activities of PT. Sido Muncul during the COVID-19 pandemic, began on March 2, 2020. Mapping was then done per attribute.

Table 3

Content Analysis of CSR Activities News of PT. Sido Muncul (Attribute A)

\begin{tabular}{llll}
\hline No. & Date & Press Name & $\begin{array}{l}\text { Attribute A (Type of } \\
\text { News) }\end{array}$ \\
\hline 1 & $22^{\text {nd }}$ of March & Detik.com & Straight News \\
2 & $23^{\text {rd }}$ of March & Detik.com & Straight News \\
3 & $5^{\text {th }}$ of April & Suara.com & Straight News \\
4 & $15^{\text {th }}$ of April & Tribunnews.com & Straight News \\
5 & $17^{\text {th }}$ of April & Detik.com & Straight News \\
6 & $18^{\text {th } \text { of April }}$ & Kompas.com & Straight News \\
7 & $23^{\text {rd } \text { of April }}$ & Kumparan.com & Straight News \\
8 & $19^{\text {th }}$ of May & Kompas.com & Straight News \\
9 & $20^{\text {th }}$ of May & Liputan6.com & Straight News \\
10 & $16^{\text {th } \text { of June }}$ & SINDONews.com & Depth News \\
11 & $17^{\text {th }}$ of June & Liputan6.com & Comprehensive News \\
12 & $22^{\text {nd }}$ of June & Tribunnews.com & Depth News \\
\hline
\end{tabular}

Source: Author's Mapping 


\section{Figure 1}

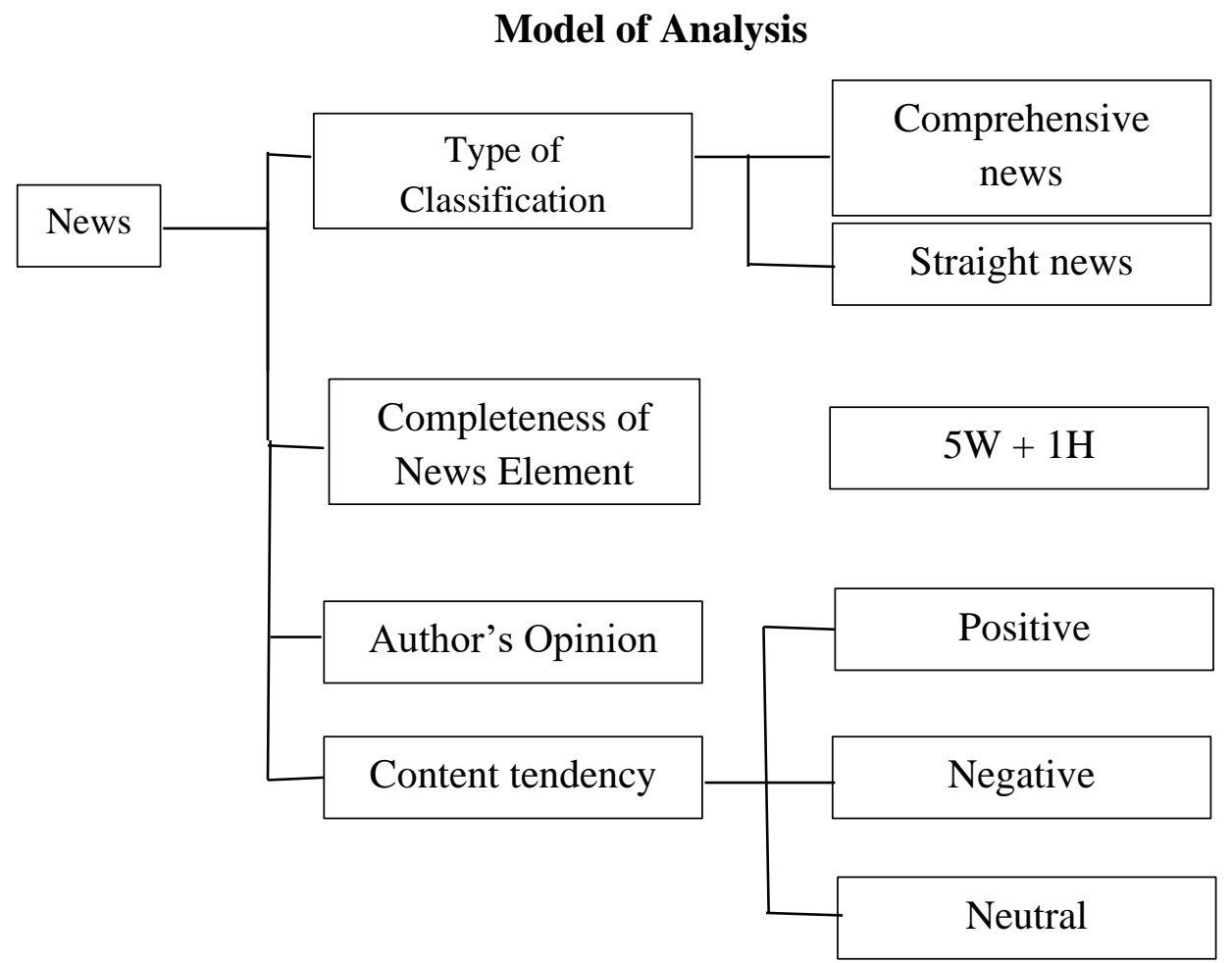

Source: Author's Model of Analysis

\section{Attribute A : News Type Classification}

Of the twelve news, nine news items are classified as straight news, two news are depth news, and one news is classified as comprehensive news. Nine news CSR activities that are straight news only provide general information about the activity of giving donations from PT. Sido Muncul during the COVID-19 pandemic. News from Tribunnews.com entitled "Help East Java Provincial Government to Press Covid-19 Victims, Sido Muncul to Distribute JSH Herbal Improve General" and news from SINDONews.com entitled "This Herbal Medicine Manufacturer Donates 1,500 Herbal Bottles for Covid-19 Patients” are classified as depth news because the authors also insert information about the history of herbs and herbal benefits for health. While news from Liputan 6.com entitled "1500 JSH Herbs to Help East Java Provincial Government Press Covid19 Victims" are classified as comprehensive news because it is not only describe about the CSR activites, but also about how East Java Governor handle this pandemic situation and how herbs are benefits for health and some prove about it's benefits in East Java society.

Straight news often does not capture the interest of the audience to read the news directly. So, this can cause consumers to not fully understand the importance 
of the CSR activities of PT. Sido Muncul done. Instead, depth news and comprehensive news contains more informations and those related to human interest so that it is better able to capture the audience's attention directly.

This can be an evaluation for public relations as a bridge of media relations to be able to fill the publicity of the CSR activities of PT. Sido Muncul with more variety, so that people are not only presented with information about the existence of CSR activities from PT. Sido Muncul, but also understands how CSR activities have an important impact on the lives of the audience.

Table 4

Content Analysis of CSR Activities News of PT. Sido Muncul (Attribute B)

\begin{tabular}{llll}
\hline No. & Date & Press Name & $\begin{array}{l}\text { Attribute B (Element } \\
\text { Completeness) }\end{array}$ \\
\hline 1 & $22^{\text {nd }}$ of March & Detik.com & 6 Element \\
2 & $23^{\text {rd }}$ of March & Detik.com & 6 Element \\
3 & $5^{\text {th }}$ of April & Suara.com & 6 Element \\
4 & $15^{\text {th }}$ of April & Tribunnews.com & 6 Element \\
5 & $17^{\text {th }}$ of April & Detik.com & 6 Element \\
6 & $18^{\text {th }}$ of April & Kompas.com & 6 Element \\
7 & $23^{\text {rd }}$ of April & Kumparan.com & 6 Element \\
8 & $19^{\text {th }}$ of May & Kompas.com & 6 Element \\
9 & $20^{\text {th }}$ of May & Liputan6.com & 6 Element \\
\hline No. & Date & Press Name & Attribute B (Element \\
& & & Completeness) \\
\hline 10 & $16^{\text {th }}$ of June & SINDONews.com & 6 Element \\
11 & $17^{\text {th }}$ of June & Liputan6.com & 6 Element \\
12 & $22^{\text {nd }}$ of June & Tribunnews.com & 6 Element \\
\hline Source & & \\
\hline
\end{tabular}

Source: Author's Mapping

Attribute B: Completeness of News Element (what, when, who, where, why and how)

All twelve news items contain a complete set of six elements namely $5 \mathrm{~W}$ $+1 \mathrm{H}$. Completeness of the six elements in one publicity can enrich the audience's knowledge of CSR activities carried out by PT. Sido Muncul. This reflects the ability of the media to be able to generate good publicity, this also shows that the media is really clear and complete in reporting the activities carried out by PT. Sido Muncul, so that it can bring a positive impact on the company.

Also, some news provides more than one resource person who gives statements that support each other in CSR activities. By providing many points of 
view in responding to these events, the audience can have a deeper understanding of the importance of the CSR activities of PT. Sido Muncul.

Table 5

Content Analysis of CSR Activities News of PT. Sido Muncul (Attribute C)

\begin{tabular}{llll}
\hline No. & Date & Press Name & Attribute C (Authors Opinion) \\
\hline 1 & $22^{\text {nd }}$ of March & Detik.com & None \\
2 & $23^{\text {rd }}$ of March & Detik.com & None \\
3 & $5^{\text {th }}$ of April & Suara.com & None \\
4 & $15^{\text {th }}$ of April & Tribunnews.com & None \\
5 & $17^{\text {th }}$ of April & Detik.com & None \\
6 & $18^{\text {th } \text { of April }}$ & Kompas.com & None \\
7 & $23^{\text {rd }}$ of April & Kumparan.com & None \\
8 & $19^{\text {th } \text { of May }}$ & Kompas.com & None \\
9 & $20^{\text {th } \text { of May }}$ & Liputan6.com & None \\
10 & $16^{\text {th }}$ of June & SINDONews.com & None \\
11 & $17^{\text {th } \text { of June }}$ & Liputan6.com & Yes \\
12 & $22^{\text {nd }}$ of June & Tribunnews.com & Yes \\
\hline
\end{tabular}

Source: Author's Mapping

\section{Attribute C: Author's Opinion}

Good news is news that is independent of the writer's opinion. That is, news is written based on facts that actually occur in the field.

Of the twelve news about the CSR activities of PT. Sido Muncul, ten news written without the author's opinion in it. While two news contains the author's opinion at the end of the article.

Tribunnews.com news entitled "Help East Java Provincial Government Press Covid-19 Victims, Sido Muncul to Distribute JSH Herbal Improve Public" and Liputan6.com news entitled "1500 JSH Herbs to Help East Java Provincial Government Press Covid-19 Victims" contains the opinion of the author in the form of a statement agreeing that herbal products from PT. Sido Muncul brings good benefits for the community in this COVID-19 pandemic situation. Even though, the two news or articles contain the opinion of the author, it should be noted that this opinion does not give a bad image to the events conducted by PT. Sido Muncul, but instead gives a good image or closes the news or article with a good impression. So, this can be interpreted as something that is very good for the development of the company image of PT. Sido Muncul in the future. 
Lukman: Publicity Of Sido Muncul

Corporate Social Responsibility News

Content During Covid-19 Pandemic

Table 6

Content Analysis of CSR Activities News of PT. Sido Muncul (Attribute D)

\begin{tabular}{llll}
\hline No. & Date & Press Name & Attribute D (Content Tendency) \\
\hline 1 & $22^{\text {nd }}$ of March & Detik.com & Positive \\
2 & $23^{\text {rd }}$ of March & Detik.com & Neutral \\
3 & $5^{\text {th }}$ of April & Suara.com & Neutral \\
4 & $15^{\text {th }}$ of April & Tribunnews.com & Neutral \\
5 & $17^{\text {th }}$ of April & Detik.com & Neutral \\
6 & $18^{\text {th }}$ of April & Kompas.com & Neutral \\
7 & $23^{\text {rd }}$ of April & Kumparan.com & Positive \\
8 & $19^{\text {th } \text { of May }}$ & Kompas.com & Positive \\
9 & $20^{\text {th }}$ of May & Liputan6.com & Neutral \\
10 & $16^{\text {th }}$ of June & SINDONews.com & Positive \\
11 & $17^{\text {th }}$ of June & Liputan6.com & Positive \\
12 & $22^{\text {nd }}$ of June & Tribunnews.com & Positive \\
\hline
\end{tabular}

Source: Author's Mapping

Attribute D: Content tendency (positive, negative or neutral)

News can contain meaning that tends to lead to certain tendencies, such as positive praise, negative criticism, or neutral neither side of one party.

Of the twelve news about the CSR activities of PT. Sido Muncul, six news leads to positive news, while six others tend to be neutral.

Six positive news is shown with an expression of appreciation from those who receive a donation of love from PT. Sido Muncul. This shows the positive impact brought by PT. Sido Muncul with the existence of these CSR activities. Meanwhile, there are six neutral news. The news is dominated by what information and information numbers without any other information that is subjective.

Positive publicity is more expected than neutral publicity. This can be an evaluation for public relations to create CSR activities that enable journalists to explore more supporting information from many sources to reinforce the important impact of doing CSR activities. Although this isn't exactly a bad thing either. by providing neutral news or articles, it can make readers have their own thoughts or impressions related to a news, without any direction of thought carried out by the author through his writing in the article or news. Of course, this can also make the news or article look sincere and not ridden by certain intentions in it, thus leading to building a good corporate image in front of the public. 


\section{CONCLUSION}

Based on the results of the analysis of the contents of the corporate social responsibility news PT. Sido Muncul in the COVID-19 pandemic in online media, researchers draw the following conclusions: Based on the five pillars proposed by Wibisono, the CSR activities of PT. Sido Muncul to meet two pillars namely Building Human Capital and Strengthening Economy. The news that the researchers have made in the discussion section is evidence that the CSR carried out by PT. Sido Muncul appears to be going well, and gets more positive news with the social activities they do during this pandemic. The news that is reported also according to the researcher is very suitable with the situation of social problems in the community, and will certainly make the image of this company better in the future.

\section{REFERENCES}

Ahditia, Puji Lestari. 2011. "Analisis Wacana Pemberitaan Pro Kontra Pemidanaan Pelaku Nikah Sirri Di Harian Seputar Indonesia."

Ahmed, Saifuddin, and Jaeho Cho. 2019. "The Roles of Different News Media Use and Press Freedom in Education Generated Participation Inequality: An Eight Country Comparative Analysis." Journal of Broadcasting and Electronic Media. doi: 10.1080/08838151.2019.1653100.

Anon. n.d. “Alexa.” 2020. Retrieved (Alexa.com).

Berger, Arthur Asa. 2011. Media and Communication Research Methods: An Introduction to Qualitative and Quantitative Approaches 2nd Edition. SAGE Publication Inc.

Danim, Sudarwan. 2002. Menjadi Peneliti Kualitatif. Pustaka Setia Bandung.

Drucker, Peter F. 1982. "The New Meaning of Corporate Social Responsibility." California Management Review. doi: 10.2307/41165066.

Garriga, Elisabet, and Domènec Melé. 2004. "Corporate Social Responsibility Theories: Mapping the Territory." Journal of Business Ethics 53(1/2):51-71. doi: 10.1023/B:BUSI.0000039399.90587.34.

Gilaninia, Shahram, Mohammad Taleghani, and Mohsen Eshghi Mohammadi. 2013. "The Role of Public Relations in Organization." Nigerian Chapter of Arabian Journal of Business and Management Review. doi: 10.12816/0003699. 
Hardhiyanti, Yunike, and Udung Noor Rasyid. 2018. "Komunikasi Bisnis Berbasis Etika Lingkungan Sebagai Csr The Body Shop Indonesia." Bricolage: Jurnal Magister Ilmu Komunikasi. doi: 10.30813/bricolage.v3i02.925.

He, Hongwei, and Lloyd Harris. 2020. "The Impact of Covid-19 Pandemic on Corporate Social Responsibility and Marketing Philosophy." Journal of Business Research. doi: 10.1016/j.jbusres.2020.05.030.

Heryanto, Gun Gun, and Shulhan Rumaru. 2015. Komunikasi Politik: Sebuah Pengantar. Ghalia Indonesia: Bogor.

Išoraitė, Margarita. 2018. "Brand Image Theoretical Aspects." Integrated Journal of Business and Economics. doi: 10.33019/ijbe.v2i1.64.

Lichtenstein, Donald R., Minette E. Drumwright, and Bridgette M. Braig. 2004. "The Effect of Corporate Social Responsibility on Customer Donations to Corporate-Supported Nonprofit." Journal of Marketing.

Lombard, Matthew, Jennifer Snyder-Duch, and Cheryl Campanella Bracken. 2002. "Content Analysis in Mass Communication: Assessment and Reporting of Intercoder Reliability." Human Communication Research. doi: 10.1111/j.1468-2958.2002.tb00826.x.

Marta, Rustono Farady, Joshua Fernando, and Laurencia Steffanie Mega Wijaya Kurniawati. 2020. "Tinjauan Peran Komunikasi Keluarga Pada Kinerja Public Relations Melalui Konten Laman Resmi Media Daring KPPPA.” Jurnal Komunikasi Pembangunan. doi: 10.22500/18202028620.

Newman, Nic, William H. Dutton, and Grant Blank. 2014. "Social Media and the News." in Society and the Internet.

Pomering, Alan, and Sara Dolnicar. 2009. "Assessing the Prerequisite of Successful CSR Implementation: Are Consumers Aware of CSR Initiatives?" Journal of Business Ethics. doi: 10.1007/s10551-008-9729-9.

Pujadi, Bambang. 2010. "Studi Tentang Pengaruh Citra Merek Terhadap Minat Beli Melalui Sikap Terhadap Merek (Kasus Pada Merek Pasta Gigi Ciptadent Di Semarang).” doi: 10.14710/jspi.v9i1.59-76.

Rahman, Mahabubur, M. Ángeles Rodríguez-Serrano, and Mary Lambkin. 2017. "Corporate Social Responsibility and Marketing Performance: The Moderating Role of Advertising Intensity." Journal of Advertising Research. doi: 10.2501/JAR-2017-047. 
Servaes, Henri, and Ane Tamayo. 2013. "The Impact of Corporate Social Responsibility on Firm Value: The Role of Customer Awareness." Management Science. doi: 10.1287/mnsc.1120.1630.

Shu, Kai, Deepak Mahudeswaran, Suhang Wang, Dongwon Lee, and Huan Liu. 2020. "FakeNewsNet: A Data Repository with News Content, Social Context, and Spatiotemporal Information for Studying Fake News on Social Media.” Big Data. doi: 10.1089/big.2020.0062.

Situmeang, Ilona Vicenovie Oisina. 2017. "Corporate Social Responsibility In Favor Of Improving Education In Society (Case Of Pt Pertamina Refinery Unit Vi Balongan).” Bricolage: Jurnal Magister Ilmu Komunikasi. doi: 10.30813/bricolage.v3i01.845.

Skard, Siv, and Helge Thorbjørnsen. 2014. "Is Publicity Always Better than Advertising? The Role of Brand Reputation in Communicating Corporate Social Responsibility.” Journal of Business Ethics. doi: 10.1007/s10551-0131863-3.

Spotts, Harlan, Marc G. Weinberger, and Michelle F. Weinberger. 2014. "Publicity and Advertising: What Matters Most for Sales?"

Tian, Zhilong, Rui Wang, and Wen Yang. 2011. "Consumer Responses to Corporate Social Responsibility (CSR) in China." Journal of Business Ethics. doi: 10.1007/s10551-010-0716-6.

Übius, Ü., and R. Alas. 2009. "Organizational Culture Types as Predictors of Corporate Social Responsibility | Organizacinès Kultūros Tipai Kaip Bendros Socialinès Atsakomybės Pranašautojai." Engineering Economics.

Wibisono, Yusuf. 2007. Membedah Konsep Dan Aplikasi CSR. Fascho Publishing.

Widhagdha, Miftah Faridl, Hermin Indah Wahyuni, and Muhammad Sulhan. 2019. "Relasi Sosial Dalam Praktik Kebijakan Csr." The Journal of Society \& Media. doi: 10.26740/jsm.v3n1.p105-125.

Widiasari, Natalia. 2012. "Analisis Isi Berita Corporate Social Responsibility (Studi Kasus PT. BM).” doi: http://dx.doi.org/10.36388\%2Fia.v1i2.713.

Yoon, Yeosun, Zeynep Gürhan-Canli, and Norbert Schwarz. 2006. "The Effect of Corporate Social Responsibility (CSR) Activities on Companies with Bad Reputations." Journal of Consumer Psychology. doi: 10.1207/s15327663jcp1604_9. 